\title{
The Holocene lithostratigraphy of Fenland, eastern England: a review and suggestions for redefinition
}

\author{
A. J. WHEELER* $\uparrow \&$ M. P. WALLER \\ * Department of Earth Sciences, University of Cambridge, Downing Street, Cambridge CB2 3EQ, U.K. \\ $\ddagger$ School of Geography, Kingston University, Penrhyn Road, Kingston upon Thames, Surrey KT1 2EE, U.K.
}

(Received 7 September 1993; revised version received 28 June 1994; accepted 20 September 1994)

\begin{abstract}
The Fenland basin is filled with unconsolidated Holocene marine and freshwater deposits. Stratigraphic studies of the basin date back to 1877 . This paper reviews the various lithostratigraphic schemes which have been proposed. Particular attention is paid to the presently accepted lithostratigraphy. Examples and a case study of a newly surveyed area are used to highlight its failings. Many of the difficulties experienced in Fenland are common to problems of lithostratigraphic classification in coastal lowland environments, as is demonstrated by reference to recent debate in the southeastern North Sea. In Fenland, as a result of the shortcomings of the various schemes, it is proposed that a new lithostratigraphy with formal stratotypes is devised. Suggestions are made as to the form this new stratigraphy could take. In the meantime, an informal lithostratigraphy should be adopted which has no regional or chronostratigraphic connotations.
\end{abstract}

\section{Introduction}

The Fenland basin of eastern England covers an area of approximately $4000 \mathrm{~km}^{2}$ (Fig. 1). During the Holocene, infilling of the basin with unconsolidated sediment has occurred in response to sea-level change and local processes (Shennan, 1986 $a, b$; Waller, 1994). Marine clastic sediments, predominant at seaward localities (around the Wash), intercalate with freshwater deposits over the central part of the basin. Around the landward edge freshwater deposits dominate, namely organic, fluviatile and lacustrine clastic deposits.

Difficulties have been encountered in defining the lithostratigraphy of these deposits due to both the discontinuous nature of peat layers and lateral changes in sediment types which are common in the clastic layers. Similar problems have confronted stratigraphers working on deposits of comparable age and palaeoenvironment in the Netherlands (Van Loon, 1981, 1985; Berendsen, 1984a) and Belgium (Baeteman, 1981, 1987). Successive lithostratigraphic schemes have been adopted for the Holocene deposits of Fenland. Unfortunately, all have their failings and the presently accepted scheme (Gallois, 1979) has been found to be impractical and imprecise when used in the field. There is need for a redefinition of the lithostratigraphy.

Lithostratigraphic classification is an essential tool to the geologist, as it provides a reliable framework upon which other data can be hung and forms the basis for geological mapping. It is therefore important

$\dagger$ Present address: School of Geosciences, The Queen's University of Belfast, Belfast BT7 INN, Northern Ireland, U.K. that the lithostratigraphy is (a) accurately defined, (b) discernible in the field and (c) widely accepted.

The International Stratigraphic Guide (Hedberg, 1976) has succeeded in promoting international agreement on the principles of stratigraphic classification and has developed an internationally accepted stratigraphic terminology and procedure. The Geological Society, London (Holland et al. 1978; Whittaker et al. 1991) has made further suggestions on procedure with regard to stratigraphic terminology and nomenclature. It is therefore imperative that these guidelines are followed in order to minimize confusion.

The main requirements of a stratigraphic classification scheme as laid down in Hedberg (1976) are that (a) litho-, chrono- and biostratigraphic schemes should be separate and (b) each unit should be clearly defined and based on a stratotype (type section) and type locality which acts as a reference. This procedure is essential in areas of complex and variable stratigraphy where it may be necessary to define several subordinate stratotypes (hypostratotypes).

\section{Fenland lithostratigraphy}

\section{2.a. Previous lithostratigraphic schemes}

The Holocene stratigraphy of Fenland was first defined by Skertchly (1877). Subsequently, a further four schemes have been proposed. Several of these have mixed litho- and chronostratigraphy. The latest, that of Shennan $(1986 b)$ is based on chronostratigraphy alone and is therefore not reviewed in this paper. The lithostratigraphic divisions of the various schemes are detailed below and represented in Figure 2. 


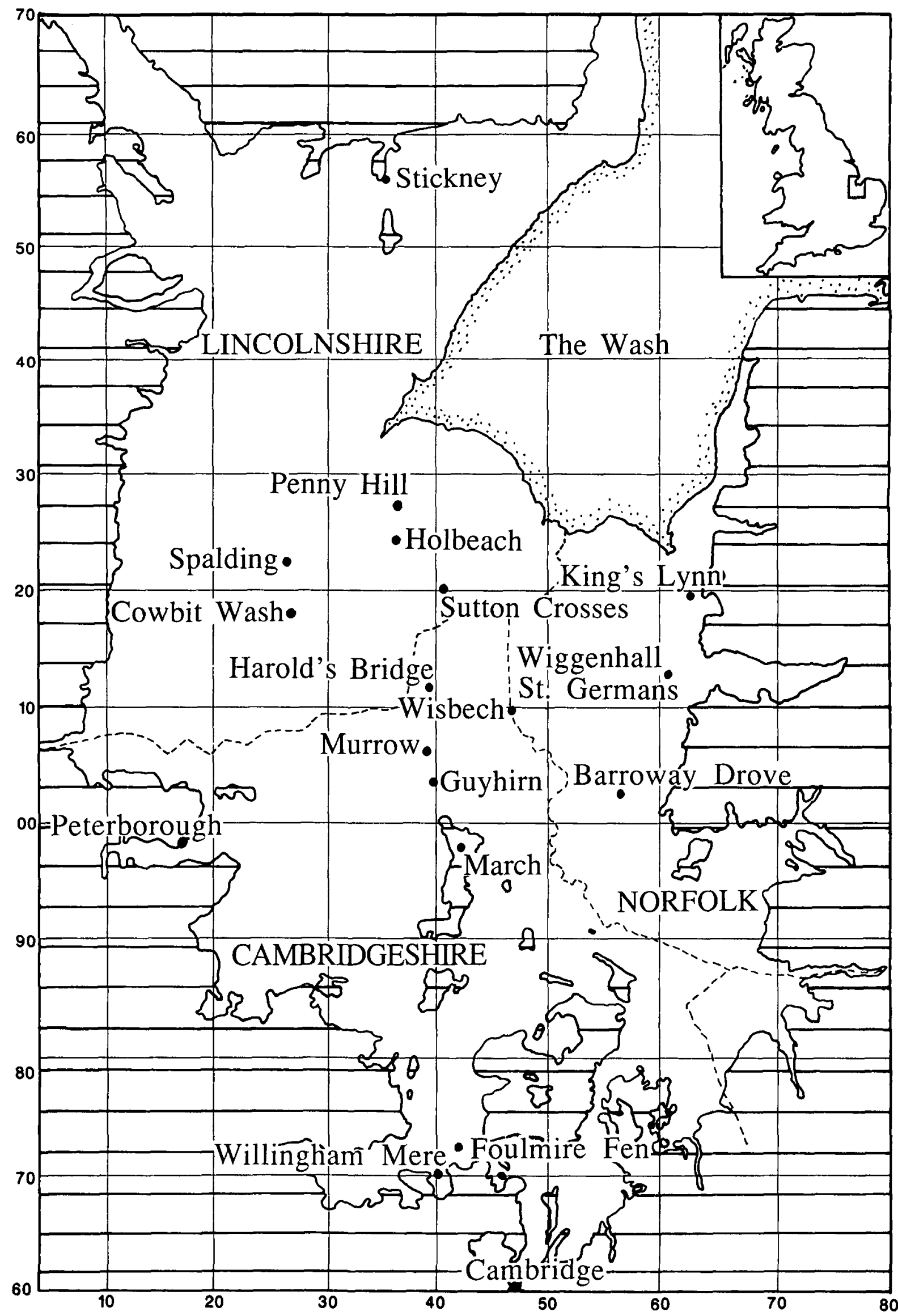

Figure 1. Fenland location map showing the location of all sites mentioned in the text. Dashed lines refer to county boundaries, areas denoted by horizontal lines represent the outcrop of pre-Holocene deposits. 


\begin{tabular}{|c|c|c|c|}
\hline Skertchly (1877) & $\begin{array}{l}\text { Godwin \& Clifford } \\
\text { (1938) }\end{array}$ & Gallois (1979) & $\begin{array}{l}\text { Wyatt (1984); } \\
\text { Horton (1989); } \\
\text { Horton \& Aldiss } \\
\text { (1992) }\end{array}$ \\
\hline \multirow{4}{*}{ Fen Silt } & Upper Silt & Terrington Beds & Terrington Beds \\
\hline & Upper Peat & Nordelph Peat & $\begin{array}{l}\text { upper leaf of the } \\
\text { Nordelph Peat }\end{array}$ \\
\hline & \multirow{5}{*}{ Fen Clay } & \multirow{5}{*}{$\begin{array}{l}\text { Barroway Drove } \\
\text { Beds }\end{array}$} & $\begin{array}{l}\text { upper member of } \\
\text { the Barroway } \\
\text { Drove Beds }\end{array}$ \\
\hline & & & $\begin{array}{l}\text { lower leaf of the } \\
\text { Nordelph Peat }\end{array}$ \\
\hline \multirow{4}{*}{ Peat } & & & $\begin{array}{l}\text { lower member of } \\
\text { the Barroway } \\
\text { Drove Beds }\end{array}$ \\
\hline & & & Middle Peat \\
\hline & & & $\begin{array}{l}\text { lower member of } \\
\text { the Barroway } \\
\text { Drove Beds }\end{array}$ \\
\hline & Lower Peat & Lower Peat & - \\
\hline
\end{tabular}

Figure 2. A comparison of the formal lithostratigraphies proposed for the Holocene deposits of Fenland.

\section{2.a.1. Skertchly (1877)}

Skertchly (1877) noted that the organic and clastic layers deposited in Fenland were very variable and discontinuous on both a local and regional scale. It was not, in the opinion of Skertchly, possible to correlate over large distances on the basis of lithology. Therefore, a simple classification into Peat (landward) and Fen Silt (seaward) was adopted. However, different lithologies, termed clay and warp, were recognized in the Fen Silt, with Skertchly noting a general seaward increase in warp.

\section{2.a.2. Godwin \& Clifford (1938)}

Modern ideas on the evolution of the Fenland basin were developed by Sir Harry Godwin. Working in southern Fenland, Godwin sank boreholes to establish the nature of the deposits and their continuity and developed a chronology using archaeological evidence with chrono-correlation between distant sites attempted by pollen analysis.

Godwin (his lithostratigraphic scheme is most clearly set out in Godwin \& Clifford, 1938) divided the sediments of southern Fenland into four units. The lowest unit, the Lower Peat, was thickest within channels cut into the pre-Holocene sediment. The overlying Fen Clay was itself overlain by the Upper Peat which typically formed the surface sediment. The fourth, uppermost unit, the Upper Silt (also referred to as the Marine Silt and Romano-British Silt) was, in the areas investigated by Godwin, largely confined to major channel systems. The Fen Clay was described as 'dark grey-blue, slightly silty but soft and buttery to the touch. It is also exceedingly micaceous .... and grades into a light clayey silt, brown or yellow in colour' (Godwin \& Clifford, 1938, p. 339). No lithological descriptions were given of the peats or the Upper Silt.

In Godwin's archaeologically based chronology (Godwin \& Clifford, 1938; Godwin, 1940) the deposition of the Lower Peat was envisaged as not being widespread until c. $3500 \mathrm{BC}$, though it started to form in channels as early as $c$. $7500 \mathrm{BC}$. The Fen Clay was deposited between Neolithic and early Bronze Age layers at a site in southeastern Fenland (Shippea Hill) and a late Neolithic age was therefore inferred (c. 2000 to $1500 \mathrm{BC}$ ). Romano-British finds from within the channel silts led Godwin \& Clifford (1938) to conclude that the Upper Silt was both deposited and occupied during the Romano-British period. Subsequent radiocarbon dating (here all radiocarbon dates are given in BP, uncalibrated radiocarbon years before AD 1950) resulted in the modification of this chronology. Willis (1961) indicated that the Fen Clay was deposited between $c .4690 \mathrm{BP}$ (in the more seaward areas) and c. 4195 BP (at its inland limit), while Churchill (1970) indicated that deposition of the Upper Silt occurred between c. 3250 and c. $2250 \mathrm{BP}$.

\section{2.a.3. Gallois (1979)}

Gallois $(1978,1979)$ mapped the Holocene deposits of the King's Lynn area. New names were applied to the four-fold lithostratigraphy of Godwin \& Clifford (1938), with the exception of the Lower Peat. Although brief lithological descriptions are given, there is no reference to type sections and the units are partly redefined on age.

The Fen Clay was renamed the Barroway Drove Beds. Barroway Drove is an area from which surface peats have disappeared in historic times. It was therefore presumed that the inorganic sediments which crop out at the surface here pre-date the Upper Peat. The Barroway Drove Beds were defined as consisting of very soft, wet, interlaminated clays and silts with occasional burrows. Former tidal creeks filled with silt and very fine-grained sand occur. Gallois stated that this unit differed from the Terrington Beds (Upper Silt) only in colour, being shades of grey, and by the presence of numerous water-filled, peat root-holes (from the overlying Nordelph Peat).

The Nordelph Peat overlies the Barroway Drove Beds (the term was also adopted for surface peats lying beyond the inland limits of the marine deposits) and was said to consist 'largely of reed stems and rhizomes and only in those areas close to the edge of the Fenland does it contain appreciable quantities of wood' (Gallois, 1979, p. 34). These deposits were 
believed to have accumulated between 4000 and $2000 \mathrm{BP}$, although we are also told in Gallois (1979) that the unit continued to form until the reclamation works of the 17 th to 19 th centuries.

The uppermost Terrington Beds include 'the present-day salt marsh deposits ... and similar deposits inland which have been reclaimed since and during Roman times' (Gallois, 1979, p. 34). The base of the Terrington Beds was defined as the disconformable upper contact of the Nordelph Peat. In the more northerly areas the Terrington Beds rest on intertidal deposits passing laterally into the Nordelph Peat. The disconformity was, following Churchill (1970), dated at between c. 3250 and $2250 \mathrm{BP}$. The Terrington Beds were defined as consisting of finely laminated, dull, slightly reddish-brown clays and pale-brown silts with most of the original bedding destroyed. The unit contains former tidal creeks infilled with silt and very fine-grained micaceous sand.

\section{2.a.4. Modifications applied to the Gallois scheme in the Peterborough and Spalding regions}

As a result of the publication of Mineral Assessment Reports (Booth, 1981, 1982), a geological map (Wyatt, 1984) and an associated memoir (Horton, 1989), a modified form of the Gallois (1979) scheme has been applied in the Peterborough region. Here, further intercalations between organic and clastic sediments are evident. Peat layers within the Barroway Drove Beds were referred to as ?Lower Peat by Booth (1981, 1982) and a Middle Peat was defined by Horton (1989). Wyatt (1984), in addition, subdivided the Barroway Drove Beds into upper and lower members. The Nordelph Peat was divided into two units called the upper and lower leaves, with the lower leaf separating the upper and lower Barroway Drove Beds. The upper Barroway Drove Beds was stated as being more silty than the lower Barroway Drove Beds (Horton, 1989). This modified stratigraphy has now been extended to the Spalding area (Horton \& Aldiss, 1992).

\section{2.b. Difficulties with the schemes}

Skertchly (1877), realizing the complexity of the Fenland deposits, avoided correlation on the basis of lithology. However, his scheme of lithostratigraphic classification merely informs us that the sediments become dominated by clastic deposits seaward and organic deposits landward. This simplification is inadequate for most present studies.

Before the more recent classification schemes are reviewed it should be stated that none were devised as formal lithostratigraphies to cover the whole basin. They have, however, subsequently been formalized and extrapolated to new areas by the original author or others.

Godwin worked in southern Fenland where the
Holocene deposits can be readily divided into four parts and where there is a very broad correspondence between lithology and stratigraphic position. The lithostratigraphic scheme devised reflected this. Godwin also made some effort to demonstrate a correspondence in age. As it appeared unnecessary, no attempt was made to restrict the usage of the terminology devised to units of lithology, stratigraphic position or time and they became synonymous with all three (see, for example, Churchill, 1970; Godwin, 1978; Seale, 1974, 1975a, b; Seale \& Hodge, 1976; Willis, 1961).

Although difficulties with this scheme have largely arisen through its application to other parts of Fenland (see below), research in recent years has demonstrated that the simple relationship between lithology, stratigraphic position and time of deposition envisaged by Godwin and others does not apply even within southern Fenland. This region is divided by upland extending north from the Cambridge area to March (Godwin \& Clifford, 1938; Waller, 1994) with tripartite sequences found on both sides of this divide. Correlation between the two sequences was attempted using pollen analysis (Godwin \& Clifford, 1938; Godwin, 1940) and subsequently radiocarbon dating (Willis, 1961). The changes in pollen stratigraphy used by Godwin have now been shown to be related to changes in sedimentary environment (Waller, 1994), while the early attempts at radiocarbon dating were inadequate (samples were not always taken from sediment contacts and in some cases were from locations where the tripartite sequence does not occur). Radiocarbon dating has now demonstrated that on the eastern side of the divide the sediment body ascribed to the Fen Clay was deposited between 5800 and $3800 \mathrm{BP}$ and on the western side between 4000 and $3200 \mathrm{BP}$ (Waller, 1994).

The scheme of Godwin \& Clifford (1938) invites us to correlate sequences on the basis of lithology. Lithology, however, does not reflect time of deposition but sedimentary environment. At any one time within the Fenland basin a series of depositional environments, arranged in a spatial zonation, will have existed. As a result, lithological characteristics would be expected to change laterally and vertically, with changes in the relative position and extent of these sedimentary environments occurring through time. That this is the case and that substantial bodies of Holocene inorganic sediment in Fenland cannot, away from the rather enclosed embayments of southern Fenland, be separated on lithology, can be readily demonstrated. For example, the deposits found overlying and underlying a peat layer, exposed during the construction of the Wisbech bypass, which, following Godwin's scheme, would have been termed Fen Clay and Upper Silt, cannot be separated on lithology. In the $7 \mathrm{~km}$ of recorded section (Alderton \& Waller in Waller, 1994) considerable variations occur 
9

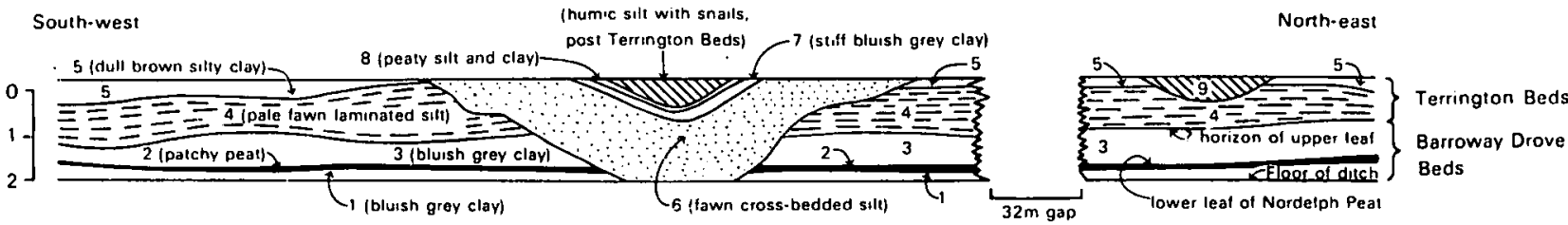

Figure 3. Section through Holocene deposits east of Harold's Bridge (Horton, 1989). The Terrington Beds lie directly upon the Barroway Drove Beds with the 'lower leaf of Nordelph Peat' occurring within the Barroway Drove Beds. The level of the Nordelph Peat (sensu Gallois, 1978) is termed '?horizon of upper leaf'. The numbers relate to the lithologies as follows: 1 - bluish grey clay, 2 - patchy peat, 3 - bluish grey clay, 4 - pale fawn laminated silt, 5 - dull brown silty clay, 6 - fawn crossbedding silt, 7 -stiff bluish grey clay, 8 - peaty silt and clay, 9 - humic silt with snails post Terrington Beds.

in both clastic units, but one particular lithology cannot be said to predominate in either.

Gallois (1979) essentially applies Godwin's fourpart division to an area (east of Wisbech) where there is no apparent difference in lithology between the clastic layers. His units have to be separated on stratigraphic position or apparent age. The latter is contrary to the principles of stratigraphic classification (Hedberg, 1976) and impracticable for field mapping which, at least over short distances, must rely on stratigraphic position or lithology for correlation. It should also be noted that, because of a general similarity with Godwin's scheme, despite Gallois' definitions, his terms have acquired lithological connotations. The Barroway Drove Beds are generally regarded as being comprised of finer sediments than the Terrington Beds (see the comments on Wyatt's and Horton's work below).

Difficulties with the four-part schemes and using stratigraphic position for correlation arise in areas where more (or less) than four units can be recognized. Chronological or lithological assumptions concerning the relationship of a particular sequence to the fourpart scheme must be made. That a four-part system of lithostratigraphic division is not applicable to the whole of the Fenland basin has been evident since the 1930s. Edmunds (in Godwin \& Godwin, 1933) recorded four peat layers at Wiggenhall St Germans on the eastern side of Fenland [though recent work close to this site has indicated that the basal layer is probably not of Holocene age and the uppermost layer may not be in situ; Waller (1994)], while stratigraphic profiles in Godwin \& Clifford (1938) indicate additional peat layers between Peterborough and Guyhirn. Subsequent work has demonstrated the presence of such units in Lincolnshire, near Spalding (Smith, 1970; Shennan, 1986a; Horton \& Aldiss, 1992) and Holbeach (A. J. Wheeler, unpub. Ph.D. thesis, Univ. Cambridge, 1994), Cowbit Wash (Shennan, 1986a), the Stickney region (Waller, 1994) and in north Cambridgeshire (Booth, 1981, 1982; Wyatt, 1984; Shennan, $1986 a$; Horton, 1989; Waller, 1994).

The work of Wyatt (1984), Horton (1989) and Horton \& Aldiss (1992) demonstrates the problems of attempting to fit Gallois' (1979) scheme to sequences with which it does not comply. Figure 3 shows a section taken from Horton (1989). Although only one peat is present, the terminology of Wyatt (1984) is applied by assuming the Terrington Beds lie directly upon the Barroway Drove Beds, and the contact between the laminated silt and bluish grey clay is referred to as '?horizon of upper leaf (Nordelph Peat)'. The Barroway Drove Beds are divided into the upper and lower members by the peat unit. However, an alternative application of the Gallois/Wyatt terminology can be suggested, which is equally valid given the definitions of these units. The alternative places all the material above the single peat unit in the Terrington Beds and considers the clay layer at the base of this unit as a facies change. Similar lithological successions have been reported by Waller (1994) several kilometres to the south near Murrow and by Wheeler (unpub. Ph.D. thesis, Univ. Cambridge, 1994) to the north at Sutton Crosses (see Section 2.c). In these areas, if chronostratigraphy is applied, the latter would appear the 'correct' interpretation. At Murrow the body of sediment mapped by Wyatt (1984) as part of the upper Barroway Drove Beds has been shown to post-date $2130 \pm 50$ BP (Q-2590) (Waller, 1994).

Application of Gallois' scheme is particularly problematic around the inland edge of Fenland. Problems arise where stratigraphic units (the marine brackish clays) are absent. In such circumstances the Lower Peat cannot be distinguished from the Upper Peat (Nordelph Peat). Gallois' (1979) solution (extending the term Nordelph Peat to cover such areas) seems inappropriate given that the peat is frequently lithologically different in and outside the limits of marine sedimentation (see, for example, Godwin \& Vishnu-Mittre, 1975; Wheeler, 1992). The complexity of the stratigraphic column becomes a problem in areas close to where major rivers (e.g. the Great Ouse, Nene, Welland, Cam) enter the Fenland basin. Additional units, freshwater shell marls and alluvium, interdigitate with the deposits of the basin. Holmes (1970), for example, defined seven stratigraphic units in the Cambridge region. The types of sedimentary sequences found in such areas are illustrated in Figure 4. The two stratigraphic columns, both from close to where the Great Ouse enters Fenland, are taken from 


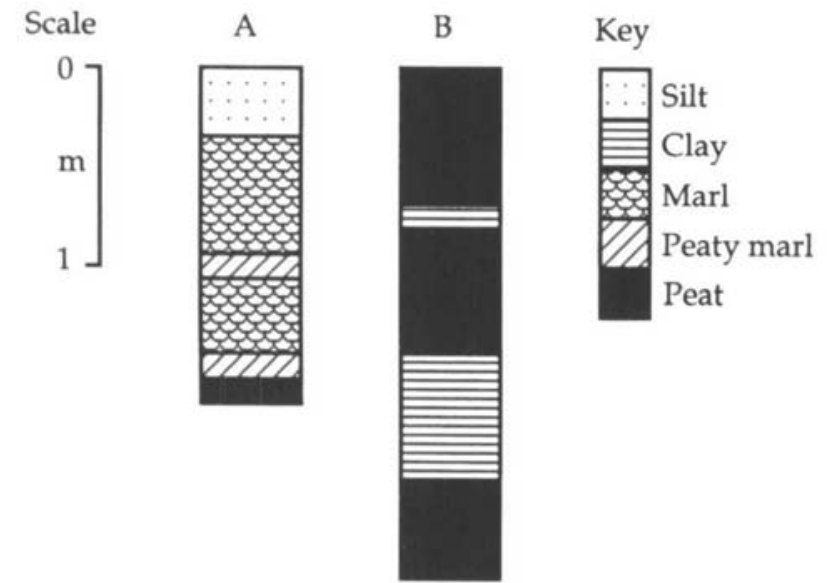

Figure 4. Holocene lithostratigraphy from two boreholes on the southern edge of Fenland near Earith. A: Willingham Mere; B: Foulmire Fen (from Waller, 1994).

sites $3.5 \mathrm{~km}$ apart. At Willingham Mere all the sediments are of freshwater origin; the lower clay at Foulmire Fen was deposited in a marine/brackish environment (Waller, 1994).

In addition to the above problems, the units of both Godwin \& Clifford (1938) and Gallois (1979) are illdefined. Godwin's scheme suffers from a lack of adequate descriptions and makes no reference to type sections. Gallois (1979) gives lithological descriptions for all the units, although fails to define a stratotype, merely making reference to rather broad type areas.

\section{2.c. The Terrington Beds in the Holbeach area, Lincolnshire}

The difficulties associated with using the Gallois (1979) scheme of lithostratigraphic classification in the field can be further demonstrated by reference to recent work undertaken in the Holbeach area of south Lincolnshire (A. J. Wheeler, unpub. Ph.D. thesis, Univ. Cambridge, 1994). Here, various sediment types and their associations have been defined. A schematic cross-section through the area showing informal lithostratigraphic units is provided in Figure 5.

The sand-silt-clay unit in the northern part of the area was deposited in a foreshore environment. Boreholes and a section near Penny Hill show two phases of deposition in the upper $3 \mathrm{~m}$ marked by slight fining upward sequences. The youngest depositional phase grades up into clayey silt, although this is only preserved in a few localities. The deposits of these two phases are lithologically similar and differentiation is difficult in most cases; for this reason they are treated as one lithostratigraphic unit. Borehole data suggest that this unit reaches a thickness in excess of $22 \mathrm{~m}$.

The sediments in the southern part of the area are in sharp contrast to those found in the north. Blue/grey clayey silts, deposited in a brackish/marine environment, intercalate with freshwater peats. Peat formation ceased at $2260 \pm 40 \mathrm{BP}$ (SRR-4585) at
Sutton Crosses, comparable with other dates (see Waller, 1994) from the top contact of the Nordelph Peat (sensu Gallois, 1979). As many as three peat layers have been identified in the area resulting from an increased tendency for interruption of peat formation by clastic deposition towards the seaward limit of peat growth.

The upper peat unit is overlain by a clay, this sequence being very similar to that found by Horton (1989) (Fig. 2) and by Waller (1994) at Murrow. The contact between this clay and an overlying silty clay and clayey silt is characteristically gradational $(>10 \mathrm{~cm})$ and marked by the deposition of silt laminae which increase in frequency up-section. A transition to saltmarsh is envisaged (A. J. Wheeler, unpub. Ph.D. thesis, 1994; Wheeler, 1994).

Two phases of saltmarsh deposition are represented by orange/brown silty clay to clayey silt units. Archaeological evidence (Green, 1961; Hallam, 1970; Smith, 1970; A. J. Wheeler, unpub. Ph.D. thesis, Univ. Cambridge, 1994) suggests that these units are comparable in age to the Terrington Beds of Gallois (1979). Each unit fines upward and becomes finer grained landward. Sediment was deposited on the marsh by means of the saltmarsh creek system. Consequently, the lithology is locally strongly controlled by the proximity of the former saltmarsh creeks. These are far more numerous than represented in Figure 5 and tend to obscure the region patterns outlined above. The saltmarsh creeks have been subsequently infilled by sand-silt-clay. Associated with the former creeks are storm-induced overbank deposits and levees.

Chronostratigraphic correlation between the deposits of the north and south is complicated by the unconformable contact between the foreshore and saltmarsh sediments. It is reasonable to assume that the two phases of deposition recognized in the foreshore sediments are isochronous with the two phases of saltmarsh formation. However, this cannot be substantiated.

Problems exist when trying to apply the stratigraphy of Gallois (1979) to these deposits. The orange/brown silty clay and clayey silt units in the south can be assigned to the Terrington Beds on the basis of age and colour. However, the base of the Terrington Beds is not so easy to place. The clay unit lies stratigraphically above the peat unit and has a clear basal contact, whereas its upper contact is gradational with the overlying unit. On the basis of stratigraphic position it would seem logical to place the basal contact of the Terrington Beds as the contact between the peat and clay units. However, the grey clay unit shows greater affinities, in both facies and lithology, to the intercalated clay below, rather than the orange/brown clayey silts above. In addition, Gallois (1979) states that the Barroway Drove Beds can be distinguished from the Terrington Beds on the basis of 
S

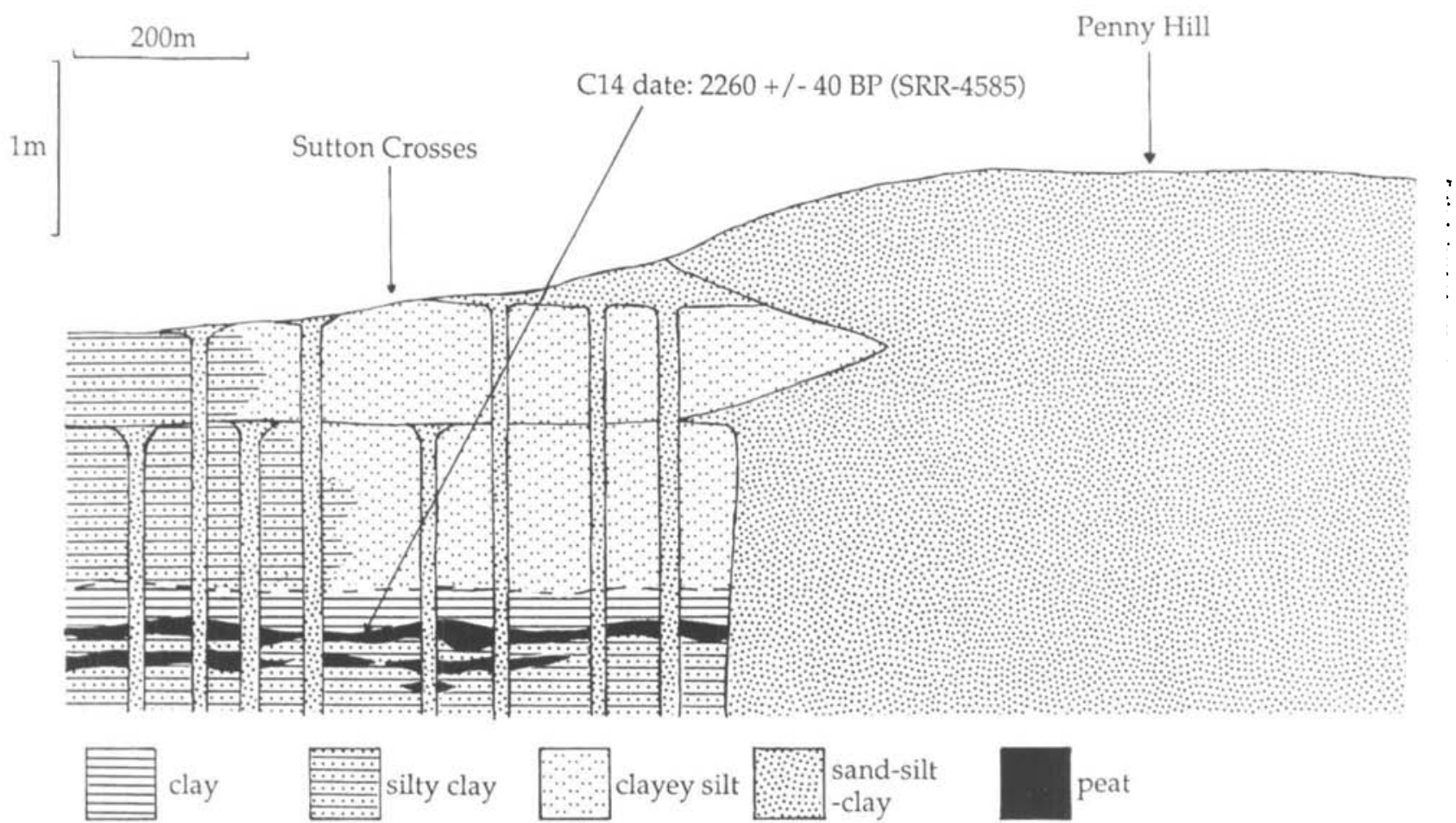

Figure 5. Generalized cross-section through the Holbeach area, north-central Fenland. Undifferentiated sand-silt-clays exist in the north of the area, whereas the clastic deposits in the south range from clays to clayey silts. In the south, attention should be drawn to multiple peat layers, lateral lithological variation within units and the effect of numerous channels and associated levees. Channels are represented schematically being more numerous and thinner in reality. Gradational contacts are represented by dotted lines, sharp contact by solid lines and lateral lithological change by no lines. The lithological contact of the peat units are also gradational.

colour, the former being grey and the latter reddishbrown. In similar circumstances Horton (1989) classified a clay unit as the upper member of the Barroway Drove Beds with an inferred position for the upper leaf of the Nordelph Peat (Fig. 3). However, nowhere in the Holbeach area has a peat unit been found to overlie the clay, making the inference of an upper leaf of the Nordelph Peat unjustified. Alternatively, with the top of the peat unit dated to $2260 \pm 40 \mathrm{BP}$ (SRR4585), if Gallois' (1979) scheme is applied chronostratigraphically then the peat unit correlates with the Nordelph Peat and the clay with the Terrington Beds.

Wyatt (1984) used the occurrence of two peat layers in the Peterborough area [where such a sequence appears to be uncommon (Waller, 1994]) to subdivide the Nordelph Peat and Barroway Drove Beds. The Holbeach study has revealed up to three peat layers and a greater number may exist. Were the logic of Wyatt (1984) to be followed, a middle leaf of the Nordelph Peat and corresponding middle members of the Barrow Drove Beds would be defined. Where the peat layer is not present, which is the general situation, its stratigraphic position would have to be inferred.

In the northern part of the area, a seemingly simpler situation exists with the Terrington Beds represented by one unit of sand-silt-clay. However, problems arise when it is considered that this sand-silt-clay unit can be traced to a maximum depth of $22.56 \mathrm{~m}$ (A. J. Wheeler, unpub. Ph.D. thesis, Univ. Cambridge, 1994). As the Gallois (1979) stratigraphy has chronostratigraphic connotations, assigning all of these sediments to the Terrington Beds would imply that the whole succession was deposited between c. $3250 \mathrm{BP}$ and the present. This scenario, although not disproved, is highly unlikely. The $3250 \mathrm{BP}$ isochron cannot be defined in the foreshore facies due to a lack of datable material. Gallois (1979) states that the Terrington Beds rest on intertidal deposits. As the Terrington Beds in the northern part of the area are also intertidal, differentiation on this basis is similarly not possible.

In view of the above difficulties it would appear that the present lithostratigraphic scheme employed by the British Geological Survey (BGS) (that is, Gallois, 1979; Wyatt, 1984; Horton \& Aldiss, 1992) is unsuitable for the Holbeach area.

\section{Lithostratigraphic classification in coastal lowlands} 3.a. Analogous stratigraphic problems

Problems with lithostratigraphic classification, similar to those outlined from Fenland, have been experienced 
in the coastal plane of the southeastern North Sea (the coasts of northeastern France, Belgium, The Netherlands and Germany). As in Fenland, these problems arose primarily because of the variability of sediments deposited in coastal lowlands.

It is characteristic of sediments deposited in such areas that they are subject to lateral facies changes and possess diachronous lithological contacts. Lateral facies change may occur over tens of kilometres, but have the tendency to be ignored by stratigraphers working on a more localized scale. This scenario is true of The Netherlands where Van Loon (1981) also notes that it is often not clear where to place minor lithologies. This is particularly true of peat lenses within marine clastic units.

Two systems of lithostratigraphic division (that of Zagwijn \& Van Staalduinen, 1975, and W. Roeleveld, unpub. Ph.D. thesis, Vrije Univ. Amsterdam, 1974) are available in The Netherlands. Under the Zagwijn \& Van Staalduinen lithostratigraphy, the marine, coastal, lagoonal and perimarine Holocene deposits of The Netherlands are grouped into the Westland Formation, which is subdivided into the Older and Younger Dunes, Dunkirk Deposits, Calais Deposits, Gorkum Deposits, Tiel Deposits, Basal Peat and Holland Peat. Fluviatile sediments not deposited in the perimarine area are included in the Betuwe Formation.

Although used by the Geological Survey of The Netherlands, several authors have raised objections to the Westland Formation. The available descriptions are both vague, and ineffective as field guides (Van Loon, 1981). The Westland Formation is described as "consisting of alternations of coarse to fine sands, light to heavy clay and peat; almost all possible combinations of the lithostratigraphic units may occur" (translated from Zagwijn \& Van Staalduinen, 1975 , p. 365 by Van Loon, 1981). The base of the unit and underlying deposits are not described (the underlying units being pre-Holocene) and the upper boundary is poorly and erroneously defined as the local land surface. Whether this is the land surface in 1975 or another year is not stated. Moreover, in places the Westland Formation is overlain by recent fluvial deposits of the Betuwe Formation. Three stratotypes are defined but neither are distinguished as paramount (holostratotype). Type areas are indicated but not type locations for the stratotypes.

The subdivisions of Zagwijn \& Van Staalduinen (1975) are based primarily on age and genesis and not on lithology (Brouwer, 1976). For example, the Tiel and Gorkum deposits cannot be distinguished on the basis of lithology and have therefore to be radiocarbon-dated (Berendsen, 1984a). The river deposits of the Rhine and Meuse are included in the Betuwe Formation unless deposited in the perimarine area where they are considered to be part of the Westland Formation. However, the perimarine area (sensu Hageman, 1969) is a genetic concept which refers to "the area where the sedimentation or seditation took place under the direct influence of the relative sea-level movements but where marine or brackish sediments themselves are absent " (Hageman, 1969, p. 377). Not only are the deposits of the Betuwe Formation lithologically indistinguishable from those of the perimarine area, but this distinction has proven particularly problematic as recent work (Berendsen, $1984 b$ ) has found little evidence to support the existence of a perimarine area (sensu Hageman, 1969).

Another of the problems with the Zagwijn \& Van Staalduinen (1975) scheme has been the adoption of pre-existing terms which have previously been used non-lithostratigraphically. The genetic and chronostratigraphic connotations associated with the terms Calais and Dunkirk have proved particularly difficult to detach (Berendsen, 1984a).

In the scheme of W. Roeleveld (unpub. Ph.D. thesis, Vrije Univ. Amsterdam, 1974), the North Sea Group, synonymous with units of the Westland Formation, is subdivided into the Wold Formation (peat) and the Groningen Formation (clastics) which are defined solely on lithology. However, proper descriptions and stratotypes are not given (Van Loon, 1981; Berendsen in Van Loon, 1985) and it is not clear where to place subordinate units or even whether the Groningen Formation contains all marine clastic sediments.

Baeteman (1981) working on the sediments of Belgium coastal plain, which can be viewed as a continuation of the Dutch sequence, encountered similar problems to those experienced in the Netherlands. The Belgium sequence had been divided into three units: Calais Deposits, surface peat and the Dunkirk Deposits. As in The Netherlands, serious confusion existed in the literature as to the exact definition of the terms Calais and Dunkirk. The surface peat (regarded as the dividing unit) is not always present and because similar environments existed throughout the infilling of the coastal plain, the Calais and Dunkirk deposits cannot be differentiated lithologically (Baeteman, 1981).

\section{3.b. Attempted solutions}

The problems of distinguishing stratigraphic units within deposits which are lithologically similar has been overcome by Allen (1987) and Allen \& Rae (1987) for the saltmarsh deposits of the Severn estuary. The late Holocene sediments are divided into four morphostratigraphic units (Wentlooge, Rumney, Awre and Northwick formations) on the basis of their consistent altitude. However, in this respect the Severn estuary is unusual; in other areas, including Fenland, altitudinal correlation is made untenable by pronounced consolidation (Waller, 1994; A. J. Wheeler, unpub. Ph.D. thesis, Univ. Cambridge, 1994). 
Some of the problems of defining deposits of coastal lowlands by conventional stratigraphic procedures (cf. Hedberg, 1976; Holland et al. 1978; Whittaker et al. 1991) can be avoided by the use of profile types (Barckhausen, Preuss \& Streif, 1977; Streif, 1978). This system of geological mapping has been employed for the deposits of the coastal plain of Belgium (Baeteman, 1981; Baeteman, 1985; Baeteman \& Paepe, 1991), Germany (Barckhausen \& Streif, 1978) and The Netherlands (De Jong, Hageman \& Van Rummelen, 1960). A profile type (De Jong \& Hageman, 1960) defines a sedimentary succession at a particular location based on the vertical relationship and order of sediment types (usually simplified into clastic and organic deposits). Three main profile types exist: $\mathrm{X}$ type containing only clastic units (although peat may occur at the top of the complex), $Y$ type containing intercalated clastic and peat units, and $\mathrm{Z}$ type containing only peat units (although clastic units may occur at the top or base of the sequence). Subordinate profile types can also be defined. On sequence maps (employing profile types) the geographic distribution of different types of sedimentary sequences can be represented, whereas a single unit might be represented on conventional outcrop maps [cf. the geological map of King's Lynn (Gallois, 1978)]. Sequence maps are particularly useful to those interested in the variability of the stratigraphic column, e.g. civil engineers.

Although profile type maps may be useful, such schemes cannot be considered systems of stratigraphic classification. Although the degree of intercalation between deposits is categorized, correlation on the basis of lithology or time is not expressed, though may be implied (possibly falsely). Furthermore, in our experience the scheme is not a good aid to communication with complexes, profiles and sequences denoted by numbers and letters which are not easily memorized, though Baeteman (1987) claims that the system is more easily read and interpreted by the nongeologist.

Additional limitations include the need to define special profile types to classify boreholes which penetrate varying amounts of the complete sequence. Also, boreholes from different sources are recorded with differing degrees of accuracy and detail, with the result that the map produced may merely reveal differences in the accuracy of borehole descriptions.

\section{Towards a new Fenland lithostratigraphy}

One possible solution to the problems of lithostratigraphic classification in Fenland would be to adopt (as a system of lithostratigraphic division only) and modify the scheme of Gallois (1979). There are three major objections to this. Firstly, not only are chronological connotations implicit in the present definitions, but once attained, as noted above, they are virtually impossible to detach. Secondly, this, or any other four-part scheme, cannot easily be adapted to areas where such sequences are not found. Some assumptions concerning the relationship of a particular sequence to the four-part scheme have to be made. Thirdly, the divisions are ill-defined. Although the units have been given type localities, no type sections have been defined. The type localities consist of broad areas, the extent of which is not clear. As a result there are no specific sequences which constitute the standard for the definition and recognition of these units. This also means that it is unlikely that the type localities will correspond with where the units are best developed. The deposits at these localities may not even be particularly representative of the units.

An alternative new scheme of lithostratigraphic classification is now required. Within Fenland three main bodies of Holocene sediment are readily recognized and must form the basis of any classification. Namely the clastic deposits which predominate seaward, organic deposits (largely peat) and clastic deposits found where rivers enter the basin. These should be assigned to formations and stratotypes defined where they are best developed (usually where one sediment type makes up the stratigraphic column). To accommodate the within-Fenland variation in the vertical succession, separate regional sub-divisions (members) will be required with accompanying subordinate stratotypes. There are a series of natural embayments where the major rivers enter Fenland which can form the basis of this regional division, with central Fenland forming a separate region (see Waller, 1994). Correlation, to the lowest justifiable element in the hierarchy, should be made by lateral continuity and/or stratigraphic position, in addition to lithology, given the variability of the latter.

With such a scheme, boundaries will have to be drawn where the different embayments coalesce. Although stratigraphic information could be used in their definition, it is these areas where stratigraphic relationships are at present most uncertain. In some cases, the boundaries will therefore have to be of an arbitrary nature. Rather than being a problem this may serve to highlight the critical areas. Where stratigraphic correlation across a boundary is established, this information can easily be detailed as supplementary information. However, it would be neither possible nor desirable, in the absence of stratigraphic continuity, to attempt to lithostratigraphically correlate the sequences found on the edge of the basin across central Fenland.

Until such a formal scheme of lithostratigraphic classification is devised, informal terms can be used to describe the position, in a vertical succession, of a particular body of sediment. Waller (1994) used the following terms to describe the organic layers; basal peat (a peat at the base of the Holocene which is overlain by clastic sediment), intercalated peat (a peat 
which lies between two Holocene clastic layers), upper peat (a surface peat which lies above a Holocene clastic layer). The clastic sediments were named after their predominant lithology. Other than being applied to Holocene sediments, these terms have no chronological connotations.

\section{Conclusions}

The problems associated with current and former Fenland lithostratigraphic schemes fall into two main categories. Firstly, there is the disregard of stratigraphic procedure by the confusion of chrono- and lithostratigraphy. Secondly, there are the difficulties of fitting sediments deposited in coastal lowlands into simple stratigraphic schemes. In view of the failing of the present BGS lithostratigraphy as a mapping tool, it is suggested that the system be abandoned before further confusion ensues, and that a new lithostratigraphy is devised. Because of the variability of the Fenland deposits, it is not possible to devise one scheme applicable to the whole basin. Regional subdivisions and a series of stratotypes are needed. In the meantime, it is suggested that workers adopt an informal lithostratigraphy with no time connotations applied to the scheme.

Acknowledgements. This research was carried out while A. J. Wheeler held a NERC studentship at the University of Cambridge and M. P. Waller worked for the Fenland Project (funded by English Heritage). Our thanks go to all the landowners who allowed us access to their land and those who assisted in the field, too numerous to mention.

\section{References}

ALLEN, J. R. L. 1987. Late Flandrian shoreline oscillations in the Severn estuary: the Rumney Formation at its typesite (Cardiff area). Philosophical Transactions of the Royal Society of London B315, 157-74.

ALLEN, J. R. L. \& RAE, J. E. 1987. Late Flandrian shoreline oscillations in the Severn estuary: a geomorphical and stratigraphical reconnaissance. Philosophical Transactions of the Royal Society of London B315, 185-230.

BAETEMAN, C. 1981. An alternative classification and profile type map applied to the Holocene deposits of the Belgium coastal plain. Bulletin Société Belge de Géologie 90, 257-80.

BaETEMAN, C. 1985. Development and evolution of sedimentary environments during the Holocene in the western coastal plain of Belgium. Eiszeitalter und Gegenvart 35, 23-32.

BaETEMAN, C. 1987. Mapping a coastal plain-problems concerning mapping units. Geobound 1, 3-9.

Baeteman, C. \& PaEPe, R. 1991. Planning and geology in a coastal plain. Bulletin Société Belge de Géologie 100, 195-201.

Barckhausen, J., Preuss, H. \& Streif, H. 1977. Ein lithologisches Ordnungsprinzip für das Küstenholozän und seine Darstellung in Form von Profiltypen. Geologisches Jahrbuch A44, 45-77.
BarCKHAUSEN, J. \& STREIF, H. 1978. Erlauterungen zu Blatt Emden West 1:2500, Nr. 2608. Hannover: Geologische Kaart Niedersachen.

Berendsen. H. J. A. 1984a. Problems of lithostratigraphic classification of Holocene deposits in the perimarine area of the Netherlands. Geologie en Mijnbouw 63, $351-4$.

BERENDSEN, H. J. A. $1984 b$. Quantitative analysis of radiocarbon dates of the perimarine area in the Netherlands. Geologie en Mijnbouw 63, 343-50.

BooTH, S. J. 1981. The sand and gravel resources of the country between Stamford, Lincolnshire and Peterborough, Cambridgeshire: description of $1: 25,000$ sheets TFOO and TF10. Mineral Assessment Reports of the Institute of Geological Sciences, no. 80.

BooTH, S. J. 1982. The sand and gravel resources of the country around Whittlesey, Cambridgeshire: description of $1: 25,000$ sheets TF20 and TL29. Mineral Assessment Reports of the Institute of Geological Sciences, no. 93.

Brouwer, A. 1976. Inflatie in de stratigrafie. Geologie en Mijnbouw 55, 227-8.

Ch\&rCHILl, D. M. 1970. Post-Neolithic to Romano-British sedimentation in the southern Fenlands of Cambridge and Norfolk. In The Fenland in Roman Times: Studies of a Major Area of Peasant Colonisation with a Gazetteer Covering all Known Sites and Finds (ed. C. W. Phillips), pp. 132-46. Royal Geographical Society Research Series no. 5 .

De Jong, J. D. \& Hageman, B. P. 1960. De legenda voor de Holocene afzettingen op de niewe geologische Kaart van Nederland, schaal 1:50000. Geologie en Mijnbouw 39, 644-53.

De Jong, J. D., Hageman, B. P. \& Van Rummelen, F. F. F. E. 1960. De Holocene afzettingen in het Deltagebied. Geologie en Mijnbouw 39, 654-60.

Galbois, R. W. 1978. Solid and Drift Geology, King's Lynn and the Wash Sheet 145 and part of 129, 1:50,000. Southampton: Ordnance Survey.

GaLLoIs, R. W. 1979. Geological investigations for the Wash Water Storage Scheme. Report, Institute of Geological Sciences, no. $78 / 19$.

GodwIN, H. 1950. Studies of the post-glacial history of the British vegetation. III. Fenland pollen diagrams. IV. Post-glacial changes of relative land and sea-level in the English Fenlands. Philosophical Transactions of the Royal Society of London B230, 239-303.

Godwin, H. 1978. Fenland: Its Ancient Past and Uncertain Future. Cambridge: Cambridge University Press.

Godwin, H. \& ClifFord, M. A. 1938. Studies of the postglacial history of British vegetation. I. Origin and stratigraphy of the Fenland deposits near Woodwalton, Hunts. II. Origin and stratigraphy of deposits in southern Fenland. Philosophical Transactions of the Royal Society of London B229, 323-406.

Godwin, H. \& Godwin, M. E. 1933. Pollen analyses of Fenland peats at St. Germans, near King's Lynn. Geological Magazine 70, 168-80.

Godwin, H. \& Vishnu-MitTRE. 1975. Studies of the postglacial history of British vegetation. XVI. Flandrian deposits of the Fenland margin at Holme Fen and Whittlesey Mere, Hunts. Philosophical Transactions of the Royal Society of London B270, 561-604.

GreEN, C. 1961. East Anglian coastline levels since the Roman times. Antiquity 35, 21-8 and 155-6.

HaGeman, B. P. 1969. Development of the western part of 
the Netherlands during the Holocene. Geologie en Mijnbouw 48, 373-88.

Hallam, S. J. 1970. Settlement around the Wash. In The Fenland in Roman Times: Studies of a Major Area of Peasant Colonisation with a Gazetteer Covering all Known Sites and Finds (ed. C. W. Phillips), pp. 22-88. Royal Geographical Research Series, no. 5.

HedBerg, H. D. 1976. International Stratigraphic Guide: A Guide to Stratigraphic Classification, Terminology, and Procedure. New York: Wiley and Sons.

Holland, C. H., Audley-Charles, M. G., Bassett, M. G., Cowie, J. W., Curry, D., FItCH, F. J., Hancock, J. M., House, M. R., Ingham, J. K., Kent, P. E., Morton, N., Ramsbottom, W. H. C., Rawson, P. F., Smith, D. B., Stubblefield, C. J., Torrens, H. S., Wallace, P. \& WoOdland, A. W. 1978. A guide to stratigraphic procedure. Royal Geological Society of London Special Report 11, 1-18.

Holmes, S. C. A. 1970. Outline geology of the Roman Fenland and stratigraphy of the Holocene deposits near the Old West River, Cambridgeshire. In The Fenland in Roman Times: Studies of a Major Area of Peasant Colonisation with a Gazetteer Covering all Known Sites and Finds (ed. C. W. Phillips), pp. 127-31. Royal Geographical Society Research Series, no. 5.

Horton, A. 1989. Geology of the Peterborough District. Memoir of the Geological Survey, England and Wales, Sheet 158.

Horton, A. \& Aldiss, D. T. 1992. Solid and Drift Geology, Spalding Sheet 144, 1:50,000. Southampton: Ordnance Survey.

SEALE, R. S. 1974. Geology of the Ely District. Bulletin of the Geological Society of Norfolk 25, 21-36.

SEALE, R. S. 1975 a. Soils of the Ely district. Memoir of the Soil Survey of England and Wales, Harpenden.

SEALE, R.S. 1975b. Soils of the Chatteris district of Cambridgeshire. Soil Survey Special Survey no. 9, Harpenden.

Seale, R. S. \& Hodge, C. A. H. 1976. Soils of the Cambridge and Ely district. Soil Survey Special Survey no. 10, Harpenden.

ShenNAN, 1. 1986a. Flandrian sea-level changes in the Fenland. 1: The geographical setting and evidence of relative sea-level changes. Journal of Quaternary Science 1, 119-54.

Shennan, I. 1986 b. Flandrian sea-level changes in the Fenland. II: Tendencies of sea-level movement, alti- tudinal changes, and local and regional factors. Journal of Quaternary Science 1, 155-79.

SkertChLy, S. B. J. 1877. The Geology of Fenland. Memoir of the Geological Survey of Great Britain.

Smith, A. G. 1970. The stratigraphy of the northern Fenland. In The Fenland in Roman Times: Studies of a Major Area of Peasant Colonisation with a Gazetteer Covering all Known Sites and Finds (ed. C. W. Phillips), pp. 147-64. Royal Geographical Society Research Series, no. 5.

STREIF, H. 1978. A new method for the representation of sedimentary sequences in coastal zones. Proceedings of the 16th Coastal Engineering Conference, ASCE/ Hamburg, W. Germany (Aug 28-Sept 1, 1978), 1245-56.

VAN LoON, A. J. 1981. Problems of Holocene lithostratigraphy. In Quaternary Geology: a Farewell to A.J. Wiggers (ed. A. J. van Loon), pp. 353-61. Geologie en Mijnbouw 60.

VAN LoON, A. J. 1985. Problems of lithostratigraphic classification of Holocene deposits in the perimarine area of the Netherlands. Geologie en Mijnbouw 64, 211-15.

Waller, M. P. 1994. Fenland Project No. 9, Flandrian Environmental Change in Fenland. East Anglian Archaeology Monograph no. 70.

WhEELER, A. J. 1992. Vegetational succession, acidification and allogenic events as recorded in Flandrian peat deposits from an isolated Fenland embayment. New Phytologist 122, 745-56.

WheELER, A. J. 1995. Saltmarsh development from fen: analysis of late Holocene deposits from the northcentral Fenland, UK. Quaternary International (in press).

Whitraker, A., Cope, J. C. W., Cowie, J. W., Gibbons, W., Hailwood, E. A., House, M. R., Jenkins, D. G., Rawson, P. F., Rushton, A. W. A., Smith, D. G., Thomas, A. T. \& Wimbledon, W. A. 1991. A guide to stratigraphical procedure. Journal of the Geological Society, London 148, 813-24.

WILLIS, E. H. 1961. Marine transgression sequences in the English Fenland. Annals of the New York Academy of Science 95, 368-76.

WyatT, R. J. 1984. Solid and Drift Geology, Peterborough Sheet 158, 1:50,000. Southampton: Ordnance Survey.

ZaGWIJN, W. H. \& VAN StaAlduinen, C. J. 1975. Toelichting bij Geologische Overzichtskaarten van Nederland. Haarlem: Rijks Geologische Dienst. 